\title{
Effects of Temperature, Rainfall and Relative Humidity on Leaf Spot of Jackfruit Seedling and its Eco-friendly Management
}

\author{
M. S. M. Chowdhury ${ }^{1 *}$ and I. Hossain ${ }^{2}$ \\ ${ }^{1}$ Department of Plant Pathology, Sher-e-Bangla Agricultural University, Dhaka-1207, Bangladesh \\ ${ }^{2}$ Department of Plant Pathology, Bangladesh Agricultural University, Mymensingh-2202, Bangladesh \\ *Corresponding Author and Email: smc_1968@yahoo.com
}

Received: 27 November 2010

Accepted: 26 November 2011

\begin{abstract}
Experiments were carried out during 2005-08 to study the effect of weather prevalence of seedling diseases of jackfruit in different areas of Bangladesh and develop an environment friendly disease management practice. Leaf spot causal pathogen Colletotrichum gloeosporioides was identified. Incidence and severity of leaf spot at seedling stage were studied and significant variations were observed depending on weather factors. Occurrence of seedling diseases was significantly influenced by temperature, rainfall and relative humidity. Comparative effectiveness of BAU-biofungicide either alone or in combination with two fungicides viz. Cupravit and Bavistin were evaluated on jackfruit in the nursery. Among the treatments applied, Trichoderma harzianum based BAU-Biofungicide showed best result in controlling leaf spot disease.
\end{abstract}

Keywords: Jackfruit seedling, leaf spot disease, ecofriendly management, BAU-Biofungicide

\section{Introduction}

Success of an orchard depends on the quality of the planting material. The climate of Bangladesh harbors plant pathogens and provides luxuriant environment for the growth and reproduction of large number of plant pathogens which cause hundreds of different diseases of crops (Fakir, 2001).

Determining the effect of temperature, rainfall, leaf wetness and relative humidity on the formation, release and germination of inoculum in different pathosystems have been focused by many researchers worldwide (Rowe and Beute, 1975; Sutton, 1981; Pinkerton et al., 1998; MacHardy et al., 2001; Mondal \& Timmer, 2002). Based on understanding the disease epidemiology, effective control measures could be developed and implemented (Hopkins and McQuilken, 2000). Plant diseases play a major role in reducing yields of horticultural crops in the tropics (Pathak, 1980a; Rawal, 1990; Ploetz et al., 1998; Mariau, 2001). It has been estimated that production could be increased at least by $28 \%$ if the crop could be protected against various diseases and many of these diseases have been reported to be transmitted through the planting material (Rawal, 1990).

Jackfruit is grown widely in Bangladesh. However, seedling diseases of jackfruit species have not been thoroughly investigated in Bangladesh. Awasthi et al. (2005) observed that jackfruit mainly suffered from leaf spot (Phyllosticta artocarpina) and tender fruit rot (Rhizopus artocarpi [Rhizopus stolonifer var. stolonifer]). Morton (1987) mentioned important diseases including pink disease, Pelliculana (Corticium) salmonicolor, stem rot, fruit rot and male inflorescence rot caused by Rhizopus artocarpi; and leaf spot due to Phomopsis artocarpina, Colletotrichum lagenarium, Septoria artocarpi, and other fungi. Gray blight, 
Pestalotia elasticola, charcoal rot, Ustilana zonata, collar rot, Rosellinia arcuata, and rust, Uredo artocarpi occurred on jackfruit.

Little information is available about the presence, prevalence, epidemiology and management of seed and seedling diseases of fruit species in Bangladesh. As many fruit species are cultivated in close proximity in the nursery, there is potential threat for spread of inoculum in the nursery. Since diseases pose a potential threat to seedlings of fruit species by causing enormous loss in plant quality and disruption of production schedules, it is imperative to investigate nurseries to get information on the identity, epidemiology and management of the pathogen that cause diseases. This experiment was therefore, undertaken to investigate the effects of temperature, rainfall and humidity on the leaf spot disease of jackfruit and to suggest an eco-friendly management package for the disease.

\section{Materials and Methods}

\subsection{Study sites}

Major growing areas of jackfruit were identified and selected based on information gathered from different government and non-government organizations. Altogether 12 nurseries in four districts of Bangladesh were surveyed and diseases of seedlings of jackfruit were studied and recorded.

\subsection{Isolation of causal organism}

Seedlings of jackfruit were observed carefully and symptoms of the diseases were recorded following the description of Pathak (1980a), Peterson (1986), Singh (1998) and Ploetz et al. (1998). Diseased seedlings were collected and brought to the laboratory and the samples were washed thoroughly under running tap water and surface sterilized with $4 \% \mathrm{NaOCl}$. The diseased parts were then cut into $1.0 \mathrm{~cm}$ long pieces. One set of pieces was placed on three layers of wet blotters equidistantly in Perspex plates and another set placed on PDA medium. Both sets were incubated for 7 days under 12/12hr. alternate cycles of near ultra violet light and darkness at $22 \pm 2{ }^{\circ} \mathrm{C}$. Then the pathogens were isolated and identified.

\subsection{Survey of seedling diseases}

Four visits were made in the selected 12 nurseries during the growing season on one to two year-old seedlings over a period of one year. In each nursery 30 tagged seedlings were considered for disease incidence and disease severity. Moreover, data on air temperature, moisture (R.H.) and rainfall were recorded.

\subsubsection{Assessment of disease incidence and severity}

Disease incidence was assessed as percentage of plants infected with atleast one leaf spot or visible symptom. Assessment of incidence, severity and PDI of the diseases of each fruit species was calculated following Rai and Mamatha (2005).

Meteorological data on temperature, relative humidity and rainfall were collected from weather stations located at Dhaka, Rajshahi and Dinajpur throughout the study period of July 2007 to June 2008.

\subsection{Eco-friendly management trial}

The study was conducted at Sher-e-Bangla Agricultural University, Dhaka during 2007 to 2008.

\subsubsection{Preparation of nursery soil and seedlings}

The substratum was prepared by mixing soil, sand and well decomposed cow dung and sterilized with formalin (40\%) following the method of Dashgupta (1988). The earthen pots were filled up with the sterilized soil. Seeds were sown in seed bed in July 2006. Seedlings were transplanted in the earthen pots in July 2007.

\subsubsection{Treatments}

For the management of nursery diseases seven treatments viz. $\mathrm{T}_{1}=\mathrm{BAU}$ Bio-fungicide applied in soil at the time of pot preparation@2\%, $\mathrm{T}_{2}=$ Cupravit spray as foliar application @ $0.2 \%$, $\mathrm{T}_{3}=$ Bavistin as foliar spraying @ $0.2 \%, \mathrm{~T}_{4}=$ BAU Bio-fungicide foliar spray @ $2 \%, \mathrm{~T}_{5}$ 
$=\mathrm{BAU}$ Bio-fungicide applied in soil and foliar spray @2\%, $\mathrm{T}_{6}=\mathrm{BAU}$ Bio-fungicide applied in soil@2\% (once at the time of pot preparation)+ Cupravit spray @ 0.2\%, $\mathrm{T}_{7}=\mathrm{BAU}$ Bio-fungicide applied in soil @ 2\% + Bavistin as foliar spraying@0.2\% and $\mathrm{T}_{8}=$ Control (untreated) were evaluated. One seedling per pot and 15 seedlings per treatment were used. The experiment was laid out in Randomized Completely Block Design (RCBD) in the net house.

\subsubsection{Application of bio-agent}

BAU Bio-fungicide is a formulated product of Trichoderma harzianum, developed in Disease Resistance Laboratory, Department of Plant Pathology, Bangladesh Agricultural University, Mymensingh (Hossain, 2003). BAUbiofungicide was thoroughly mixed with the soil @ $6.4 \mathrm{~g} / \mathrm{m}^{2}$ soil (Lo et al., 1996).

2.4.4. Assessment of disease incidence, severity, \% disease reduction over control and \% increase of height over first count

Assessment of incidence and severity of the diseases was done by the formulae of Rai and Mamatha (2005) and Johnston (2000). Percent height increase/decrease over first count was calculated following Ali (2008).

\subsection{Data analysis}

Data on different parameters were analyzed in two factor randomized complete block design (RCBD) through computer software MSTAT-C (Anonymous, 1989b).

\section{Results and Discussion}

Investigation on seedling diseases of jackfruit in different nurseries throughout the country during 2005-2006 revealed that leaf spot was the most common disease in the nurseries. The leaf spot causal pathogen was identified as Colletotrichum. gloeosporioides. This is the first report in the country about the disease. Prevalence of similar leaf spot caused by Colletortrichum gloeosporioides was reported by Awasthi et al. (2005). They also observed that jackfruit mainly suffered from leaf spot (Phyllosticta artocarpina) and tender fruit rot (Rhizopus artocarpi [Rhizopus stolonifer var. stolonifer]) in orchards. Morton (1987) investigated the diseases of jackfruit and stated important diseases that include pink disease, Pelliculana (Corticium) salmonicolor, stem rot, fruit rot and male inflorescence rot caused by Rhizopus artocarpi; and leaf spot due to Phomopsis artocarpina, Colletotrichum lagenarium, Septoria artocarpi, and other fungi. Gray blight, (Pestalotia elasticola), charcoal rot (Ustilana zonata), collar rot (Rosellinia arcuata) and rust (Uredo artocarpi) occur on jackfruit in some regions.

\subsection{Incidence and severity of leaf spot at different experimental locations of Bangladesh}

Leaf spot, incidence and severity under three locations viz. Dhaka, Rajshahi and Dinajpur varied from 55.19-59.84\% and 43.92-45.02\%, respectively. The highest incidence and severity were recorded in Dhaka and the lowest in Dinajpur (Table 1).

Table 1. Incidence and severity of leaf spot disease of jackfruit seedling at different locations of Bangladesh

\begin{tabular}{lcc}
\hline & \multirow{2}{*}{ Locations } & \multicolumn{2}{c}{ Leaf spot } \\
\cline { 2 - 3 } & Incidence $(\%)$ & Severity $(\%)$ \\
\hline Dhaka & 59.84 & 45.02 \\
Rajshahi & 57.63 & 44.03 \\
Dinajpur & 55.19 & 43.92 \\
\hline LSD (0.01) & 7.328 & 7.229 \\
CV $(\%)$ & 5.53 & 7.09 \\
\hline
\end{tabular}




\subsubsection{Incidence and severity of leaf spot of jackfruit during different data recording times of Bangladesh}

Incidence and severity of leaf spot of jackfruit seedling varied significantly from July, 2007 to April, 2008 and that ranged from 52.48 to $61.08 \%$ and 29.55 to $56.23 \%$. The highest incidence and severity were recorded in October 2007 and the lowest were in January 2008 (Table 2).

\subsubsection{Incidence and severity of seedling disease (leaf spot) of jackfruit in different locations of Bangladesh}

Incidence of leaf spot of Jackfruit seedlings varied significantly from season to season as well as from location to location and that ranged from 50.59 to $63.60 \%$ (Table 3). The highest incidence $(63.60 \%)$ of leaf spot was observed in October 2007 at Dhaka followed by April 2008 at Dhaka and the lowest (50.59\%) was observed in January 2008 at Rajshahi. The severity of leaf spot varied significantly from season to season as well as location to location and that ranged from $29.19-57.57 \%$, where the highest severity was observed in October at Dhaka and lowest in January 2008 at Rajshahi.

Table 2. Incidence and severity of leaf spot disease of jackfruit seedling during July 2007 to April 2008 of Bangladesh

\begin{tabular}{lcc}
\hline Data recording time (Month) & \multicolumn{3}{c}{ Leaf spot } \\
\cline { 2 - 3 } & Incidence (\%) & Severity (\%) \\
\hline July, 2007 & 57.75 & 44.73 \\
October, 2007 & 61.08 & 56.23 \\
January, 2008 & 52.48 & 29.55 \\
April, 2008 & 58.91 & 46.78 \\
\hline LSD (0.01) & 7.681 & 7.229 \\
CV $(\%)$ & 5.53 & 7.09 \\
\hline
\end{tabular}

Table 3. Incidence and severity of leaf spot disease of jackfruit seedling in different locations in four different seasons of Bangladesh

\begin{tabular}{clcc}
\hline \multirow{2}{*}{ Locations } & \multicolumn{1}{c}{$\begin{array}{c}\text { Data recording time } \\
\text { (Month) }\end{array}$} & Ancidence (\%) & Severity (\%) \\
\cline { 3 - 4 } Dhaka & July, 2007 & 59.73 & 43.02 \\
& October, 2007 & 63.60 & 57.57 \\
& January, 2008 & 52.83 & 29.53 \\
& April, 2008 & 63.22 & 49.98 \\
\multirow{2}{*}{ Rajshahi } & July, 2007 & 56.88 & 44.57 \\
& October, 2007 & 61.36 & 55.64 \\
& January, 2008 & 54.03 & 29.19 \\
& April, 2008 & 58.25 & 46.73 \\
Dinajpur & July, 2007 & 56.65 & 46.60 \\
& October, 2007 & 58.28 & 55.48 \\
& January, 2008 & 50.59 & 29.95 \\
LSD (0.01) & April, 2008 & 55.25 & 43.64 \\
CV (\%) & & 7.229 & 7.681 \\
\hline
\end{tabular}


3.2. Effect of weather on the incidence and severity of leaf spot disease of jackfruit seedling

The highest temperatures prevailed from March to May $\left(28.5{ }^{\circ} \mathrm{C}\right)$; June was transitional period $\left(29.4{ }^{\circ} \mathrm{C}\right)$ and an equable temperature $28.87{ }^{\circ} \mathrm{C}$ prevailed from July to September. A fall in temperature was observed from October $(27.45$ $\left.{ }^{0} \mathrm{C}\right)$ to the end of December $\left(18.4^{0} \mathrm{C}\right)$; and the coolest period prevailed during January and February $\left(17.4{ }^{0} \mathrm{C}\right)$ as shown in Fig. 1. About $80 \%$ the annual rainfall occurred during the monsoon, (late May to mid-October). Total amounts of rainfall in the locations were 23.79, 18.45 and $15.76 \mathrm{~cm}$ at Dhaka, Rajshahi and Dinajpur, respectively. Slight rain $(0.13 \mathrm{~cm})$ was recorded in January. March and April were the least humid months, while the average relative humidity ranged from $64 \%-73 \%$. The relative humidity during June to October was above $80 \%$ and during November to February was $75 \%$. Based on the analysis of the climatic variations, four disease recording times were selected to observe the effect of weather on the incidence and severity of seedling diseases of selected fruit species. Lowest incidence and severity of leaf spot of jackfruit (52.48 and $29.55 \%$ ) were recorded in January at temperature, relative humidity and rainfall of $18.10^{\circ} \mathrm{C}, 75.33 \%$ and $2.73 \mathrm{~cm}$, respectively. On the other hand, the highest prevalence of incidence and severity were recorded (61.08\% and $56.23 \%)$ in October at temperature, relative humidity and rainfall of $27.45{ }^{\circ} \mathrm{C}, 81.33 \%$ and $14.9 \mathrm{~cm}$, respectively (Fig. $1)$.

\subsection{Relationship between weather factors and incidence as well as severity of different diseases of jackfruit seedlings}

Correlation and linear regression analysis regarding relationship between different components of climatic factor (temperature, relative humidity and rainfall) and incidence as well as severity of leaf spot disease of jackfruit seedlings revealed that temperature was positively correlated with both incidence $(\mathrm{r}=$ $0.77)$ and severity $(r=0.69)$ of leaf spot disease of jackfruit seedlings as shown in Table 4.

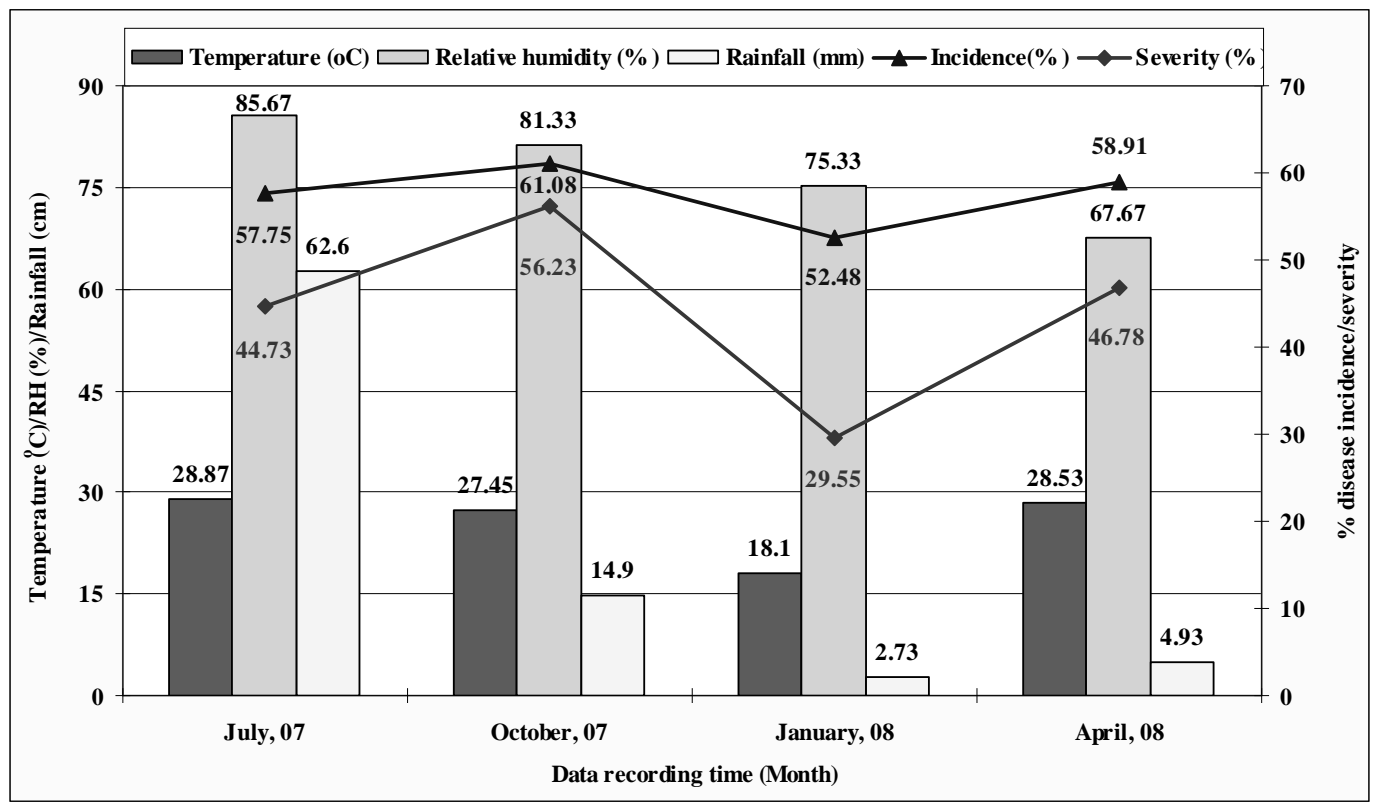

Fig. 1. Effect of different climatic factors on the incidence and severity of leaf spot of jackfruit 
Table 4. Linear regression analysis of climatic factors (temperature, relative humidity and rainfall) with the incidence and severity of leaf spot disease of jackfruit seedlings

\begin{tabular}{l|c|c|c|c|c|c}
\hline \multirow{2}{*}{ Climatic factors } & \multicolumn{2}{|c|}{ Slope $(\mathrm{b})$} & \multicolumn{2}{c|}{$\begin{array}{c}\text { Coefficient of } \\
\text { determination }\left(R^{2}\right)\end{array}$} & \multicolumn{2}{c}{ Probability $(P)$} \\
\cline { 2 - 7 } & Incidence & Severity & Incidence & Severity & Incidence & Severity \\
\hline Temperature & 0.631 & 1.801 & 0.77 & 0.69 & 0.081 & 0.125 \\
Relative humidity & 0.067 & 0.313 & 0.02 & 0.05 & 0.851 & 0.770 \\
Rainfall & 0.002 & 0.007 & 0.04 & 0.04 & 0.805 & 0.803 \\
\hline
\end{tabular}

Effects of temperature, rainfall, leaf wetness and relative humidity on the incidence and severity of disease in different pathosystems have been reported by many researchers (Rowe and Beute, 1975; Sutton, 1981; Pinkerton et al., 1998; Mac Hardy et al., 2001; Mondal and Timmer, 2002). Fitzell and Peak (1984) stated that the conidia of Colletorichum gloeosporioides were produced in lesions on leaves, defoliated branch terminals, mummified inflorescence and flower bracts over a wide range of environmental conditions (10-30 ${ }^{0} \mathrm{C}, \quad>95 \%$ relative humidity). However, prevalence of similar leaf spot caused by Colletortrichum gloeosporioides on leaves of other fruit species, viz. in guava (Pathak, 1986; Rahman et al., 2003) and mango (Pathak, 1986) had been reported to be influenced by excessive rain, high humidity and temperature.

\subsection{Eco-friendly disease management trial}

Comparative effectiveness of BAU-biofungicide either alone or in combination with chemical fungicides viz. Cupravit and Bavistin were evaluated for controlling incidence and severity of seedling disease of jackfruit.

In all treatments applied, the incidence of disease decreased gradually from August 2007 to June 2008 and the lowest was during May to June 2008 (Table 5). Highest incidence of leaf spot $(78.67 \%)$ was observed in untreated control and the lowest incidence $(28.60 \%)$ was observed when BAU Bio-fungicide applied in soil. Highest reduction of leaf spot of $63.65 \%$ over control was observed in $\mathrm{T}_{5}$ (BAU Bio-fungicide was applied in soil and top dressing @ 2\%).

The lowest severity (5.56-36.07\%) was found in August 2007 and it was gradually increased in the following months up to March 2008 and remained almost static from April 2008 to June 2008 (Table 6). In July, the severity was little higher than in the previous months. In case of untreated control, disease severity increased gradually from August, 2007 and the highest severity $(65.53 \%)$ was observed in March, 2008 and then it suddenly decreased up to $33.30 \%$ in the months of April, 2008 to July, 2008. The highest leaf spot severity $(46.63 \%)$ was observed in untreated control and the lowest severity $(8.10 \%)$ was observed in BAU Bio-fungicide applied in soil and top dressing which resulted the highest reduction $(82.63 \%)$ of disease severity over control, the lowest reduction $(43.23 \%)$ of disease severity over control was observed in Bavistin spray @ 0.2\%.

Application of treatments resulted gradual decrease of incidence in the months of August 2007 to June 2008. This may be due to growth and flashes of new leaves which were not attacked by the pathogen. Jackfruit main growth flushes appeared twice, one from July to September and the other from March to May. In July 2008, higher incidence might be due to conducive environment for the pathogen. The highest reduction $(63.65 \%)$ of disease incidence over control was observed by BAU Biofungicide applied in the soil at the time of planting and top dressing @ 2\% in every month. The lowest severity of the disease was observed in August 2007 and it was gradually increased in the following months up to March 2008 and it became almost static in April 2008 to June 2008. This might be due to low humidity and low rainfall. 
Table 5. Effect of different management practices on the incidence of leaf spot of jackfruit seedlings during the growing period of August 2007 to July 2008

\begin{tabular}{|c|c|c|c|c|c|c|c|c|c|c|c|c|c|c|}
\hline \multirow[b]{2}{*}{ 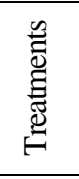 } & \multicolumn{14}{|c|}{$\%$ disease incidence } \\
\hline & $\begin{array}{c}\text { August } \\
2007\end{array}$ & $\begin{array}{c}\text { September } \\
2007\end{array}$ & $\begin{array}{c}\text { October } \\
2007\end{array}$ & $\begin{array}{l}\text { Nov } \\
2007\end{array}$ & $\begin{array}{c}\text { December } \\
2007\end{array}$ & $\begin{array}{c}\text { January } \\
2008\end{array}$ & $\begin{array}{l}\text { February } \\
2008\end{array}$ & $\begin{array}{l}\text { March } \\
2008\end{array}$ & $\begin{array}{l}\text { April } \\
2008\end{array}$ & $\begin{array}{l}\text { May } \\
2008\end{array}$ & $\begin{array}{l}\text { June } \\
2008\end{array}$ & $\begin{array}{l}\text { July } \\
2008\end{array}$ & Mean & $\begin{array}{c}\% \\
\text { reduction } \\
\text { over } \\
\text { control }\end{array}$ \\
\hline $\mathrm{T}_{1}$ & 52.77 & 45.70 & 41.07 & 41.07 & 41.07 & 41.07 & 43.27 & 43.27 & 7.697 & 7.697 & 7.697 & 21.73 & 32.83 & 58.27 \\
\hline $\mathrm{T}_{2}$ & 91.87 & 82.30 & 79.07 & 79.07 & 79.07 & 77.33 & 79.57 & 79.57 & 18.47 & 18.47 & 18.47 & 21.17 & 60.13 & 23.57 \\
\hline $\mathrm{T}_{3}$ & 85.87 & 78.93 & 76.10 & 76.10 & 76.10 & 76.10 & 77.43 & 77.43 & 18.70 & 18.70 & 18.70 & 21.87 & 58.50 & 25.64 \\
\hline $\mathrm{T}_{4}$ & 90.77 & 85.77 & 73.70 & 79.10 & 79.10 & 76.90 & 79.67 & 78.00 & 17.80 & 17.80 & 17.80 & 23.40 & 61.50 & 21.83 \\
\hline $\mathrm{T}_{5}$ & 52.37 & 42.43 & 38.73 & 37.87 & 37.87 & 35.37 & 33.70 & 33.70 & 7.943 & 7.943 & 7.943 & 9.937 & 28.60 & 63.65 \\
\hline $\mathrm{T}_{6}$ & 80.93 & 69.03 & 65.00 & 63.50 & 63.50 & 63.50 & 69.03 & 69.03 & 9.057 & 7.723 & 7.723 & 13.00 & 48.27 & 38.64 \\
\hline $\mathrm{T}_{7}$ & 70.60 & 71.00 & 61.57 & 67.13 & 66.47 & 67.13 & 73.80 & 73.80 & 6.850 & 6.850 & 6.850 & 13.83 & 48.77 & 38.01 \\
\hline $\mathrm{T}_{8}$ & 100.0 & 98.33 & 96.47 & 96.80 & 96.80 & 98.47 & 98.47 & 98.47 & 34.00 & 34.00 & 34.00 & 45.23 & 78.67 & - \\
\hline $\begin{array}{l}\text { LSD } \\
(0.01)\end{array}$ & 5.527 & 5.459 & 7.238 & 7.339 & 7.339 & 7.484 & 7.190 & 5.108 & 3.195 & 3.173 & 3.986 & 5.387 & 3.037 & \\
\hline $\begin{array}{l}\text { CV } \\
(\%)\end{array}$ & 7.74 & 7.67 & 8.36 & 9.28 & 7.62 & 5.30 & 7.16 & 6.54 & 8.22 & 8.00 & 11.59 & 10.38 & 4.05 & \\
\hline
\end{tabular}

N.B. Data represent the mean values of 3 replications; each replication was derived from 15 plants per treatment; in a column means having similar letter(s) are statistically similar at $1 \%$ level of significance by DMRT

$\mathrm{T}_{1}=$ BAU Bio-fungicide applied in soil @ 2\%

$\mathrm{T}_{2}=$ Cupravit spray @ $0.2 \%$

$\mathrm{T}_{3}=$ Bavistin spray @ $0.2 \%$

$\mathrm{T}_{4}=$ BAU Bio-fungicide foliar spray @ 2\%

$\mathrm{T}_{5}=$ BAU Bio-fungicide applied in soil and top dressing @ 2\%

$\mathrm{T}_{6}=$ BAU Bio-fungicide applied in soil @ 2\% and Cupravit spray @ 0.2\%

$\mathrm{T}_{7}=\mathrm{BAU}$ Bio-fungicide applied in soil @2\% and Bavistin spray @ 0.2\%

$\mathrm{T}_{8}=$ Untreated control 
Table 6. Effect of different management practices on the severity of leaf spot of jackfruit seedlings during the growing period of August 2007 to July 2008

\begin{tabular}{|c|c|c|c|c|c|c|c|c|c|c|c|c|c|c|}
\hline \multirow{2}{*}{ 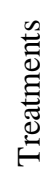 } & \multicolumn{14}{|c|}{$\%$ disease severity } \\
\hline & $\begin{array}{c}\text { August } \\
2007\end{array}$ & $\begin{array}{c}\text { September } \\
2007\end{array}$ & $\begin{array}{c}\text { October } \\
2007\end{array}$ & $\begin{array}{c}\text { Novembe } \\
\mathrm{r} \\
2007\end{array}$ & $\begin{array}{c}\text { December } \\
2007\end{array}$ & $\begin{array}{c}\text { January } \\
2008\end{array}$ & $\begin{array}{c}\text { February } \\
2008\end{array}$ & $\begin{array}{c}\text { March } \\
2008\end{array}$ & $\begin{array}{l}\text { April } \\
2008\end{array}$ & $\begin{array}{l}\text { May } \\
2008\end{array}$ & $\begin{array}{l}\text { June } \\
2008\end{array}$ & $\begin{array}{l}\text { July } \\
2008\end{array}$ & Mean & $\begin{array}{c}\% \\
\text { reduction } \\
\text { over } \\
\text { control }\end{array}$ \\
\hline $\mathrm{T}_{1}$ & 7.78 & 8.33 & 8.56 & 9.43 & 9.99 & 9.99 & 10.53 & 11.63 & $9.43 \mathrm{e}$ & $9.43 \mathrm{e}$ & 9.43 & 12.73 & 9.77 & 79.05 \\
\hline $\mathrm{T}_{2}$ & 19.97 & 21.63 & 22.20 & 23.30 & 24.97 & 26.63 & 27.77 & 28.87 & 22.17 & 22.17 & 22.17 & 22.17 & 23.63 & 49.32 \\
\hline $\mathrm{T}_{3}$ & 19.97 & 24.97 & 26.07 & 27.20 & 27.73 & 29.40 & 31.60 & 32.73 & 24.43 & 24.43 & 24.43 & 24.43 & 26.47 & 43.23 \\
\hline $\mathrm{T}_{4}$ & 19.40 & 20.50 & 22.73 & 23.83 & 25.50 & 27.20 & 28.87 & 30.00 & 19.97 & 19.97 & 19.97 & 19.97 & 23.13 & 50.4 \\
\hline $\mathrm{T}_{5}$ & 5.56 & 5.56 & 5.89 & 5.56 & 5.56 & 6.11 & 6.11 & 6.67 & 12.73 & 11.07 & 8.55 & 17.73 & 8.10 & 82.63 \\
\hline $\mathrm{T}_{6}$ & 12.77 & 14.97 & 16.07 & 17.17 & 18.30 & 19.43 & 20.53 & 21.63 & 15.53 & 14.43 & 14.43 & 23.30 & 17.37 & 62.75 \\
\hline $\mathrm{T}_{7}$ & 22.20 & 25.50 & 26.63 & 27.10 & 29.43 & 30.53 & 31.63 & 33.87 & 7.22 & 7.22 & 10.53 & 18.33 & 22.50 & 51.75 \\
\hline $\mathrm{T}_{8}$ & 36.07 & 45.53 & 47.73 & 52.20 & 56.63 & 59.97 & 63.30 & 65.53 & 33.30 & 33.30 & 33.30 & 33.30 & 46.63 & - \\
\hline $\begin{array}{l}\text { LSD } \\
(0.01)\end{array}$ & 3.208 & 4.750 & 5.373 & 4.910 & 5.151 & 5.101 & 3.981 & 5.867 & 3.885 & 4.198 & 3.864 & 5.274 & 2.374 & \\
\hline $\begin{array}{l}\mathrm{CV} \\
(\%)\end{array}$ & 7.35 & 9.36 & 10.05 & 8.70 & 8.56 & 8.02 & 5.95 & 8.36 & 8.83 & 9.73 & 8.91 & 10.09 & 4.40 & \\
\hline
\end{tabular}

N.B. Data represents the mean value of 3 replications; each replication was derived from 15 plants per treatment; in a column means having similar letter(s) are statistically similar at $1 \%$ level of significance by DMRT

$\mathrm{T}_{1}=$ BAU Bio-fungicide applied in soil @ 2\%

$\mathrm{T}_{2}=$ Cupravit spray @ $0.2 \%$

$\mathrm{T}_{3}=$ Bavistin spray @ $0.2 \%$

$\mathrm{T}_{4}=$ BAU Bio-fungicide foliar spray @ 2\%

$\mathrm{T}_{5}=$ BAU Bio-fungicide applied in soil and top dressing @ 2\%

$\mathrm{T}_{6}=$ BAU Bio-fungicide applied in soil @ 2\% and Cupravit spray @ 0.2\%

$\mathrm{T}_{7}=$ BAU Bio-fungicide applied in soil @ 2\% and Bavistin spray @ 0.2\%

$\mathrm{T}_{8}=$ Untreated control 
Fitzell and Peak (1984) stated that the conidia of C. gloeosporioides were produced in lesions on leaves over a wide range of environmental conditions $\left(10-30{ }^{\circ} \mathrm{C},>95 \%\right.$ relative humidity). Prevalence of similar leaf spot caused by $C$. gloeosporioides on leaves of other fruit species, viz. in guava (Pathak, 1986; Rahman et al., 2003) and mango (Pathak, 1986) had been reported to be influenced by excessive rain, high humidity and temperature.

\subsection{Effect of management practices on the height of jackfruit seedlings}

Significant variations in the height increase over first count were found under different management practices (Table 7). The maximum height $(58.97 \mathrm{~cm})$ as well as increase by $84.30 \%$ over control were observed in $\mathrm{T}_{7}$ (BAU Biofungicide applied in soil @ 2\% and Bavistin spray @ 0.2\%) followed by $\mathrm{T}_{5}$ (BAU Biofungicide applied in soil and top dressing @ 2\%).

On the other hand, the minimum height (28.33 $\mathrm{cm}$ ) over first count but $11.47 \%$ reduction over control was observed $\mathrm{T}_{3}$ (Bavistin spray @ $0.2 \%$ ). Among the treatments applied, Trichoderma harzianum based BAUBiofungicide showed excellent result in controlling leaf spot disease of jackfruit seedling. Mamatha et al., (2000) reported that soil amendment with $T$. harzianum was superior to other treatments like chemical, physical and plant extract treatments both in reducing seed mycoflora and in enhancing the germination and vigor in four different forest species tested.

BAU-Biofungicide is a new means of disease control in Bangladesh. Its efficacy in controlling seed borne, soil borne and air borne pathogens of different crops like wheat, rice, maize, pulses and legumes have been studied by many workers in Bangladesh (Hossain, 2007; Mostofa, 2009; Shultana et al., 2009 ). Use of Cupravit and Bavistin alone and in combination with BAUBiofungicide also reduced the prevalence of leaf spot disease of seedlings of fruit species.

\section{Conclusions}

The weather parameters have profound effect on the prevalence of seedling disease of jackfruit and the effect differs significantly in different weather conditions. Critical study should be conducted on host-pathogen system to find out the most appropriate time to combat the disease at minimum effort. Further, other parameters of epidemiology viz. total amount of rainfall in the growing period, leaf wetness period, vapor presser deficit, sunshine hour, microclimatic parameters including canopy temperature, relative humidity etc. should be critically evaluated to have better understanding of disease development. Trichoderma harzianum based BAU-Biofungicide, a new means of disease control in the nursery plantations, could be employed against leaf spot of jackfruit in the nurseries of Bangladesh as an eco-friendly disease management tool.

\section{References}

Anonymous, 1995. Annual Report (1994-95), Bangladesh Agricultural Research Institute, Div. Plant Path. BARI, Gazipur-1701, Bangladesh.

Anonymous. 1989. MSTAT-C, a micro computer program for the design, management and analysis of agronomic research experiments. Michigan State Univ., East Lansing, MI.

Awasthi, D. P., Sarkar, S., Mishra, N. K. and Kaisar, S. A. K. M. 2005. Disease situation of some major fruit crops in new alluvial plains of west Bengal. Environment and Ecology, 235 (Special-3): 497-499.

Dashgupta, M. 1988. Principles of Plant Pathology. Allied Publisher Private Limited. New Delhi, India. 700 p.

Fakir, G. A. 2001. List of seed borne diseases of important crops occurring in Bangladesh. Department of Plant Pathology, Bangladesh Agricultural University, Mymensingh.

Fitzell, R. D. and Peak, C. M. 1984. The epidemiology of anthracnose disease of mango inoculum sources, spore production and dispersal. Annals of Applied Biology, 104:53-59.

Hopkins, K. E., and McQuilken, M. P. 2000. Characteristics of Pestalotiopsis associated with hardy ornamental plants in the UK. Europian Journal of Plant Pathology, 106:77-85. 
Hossain, I. 2003. BAU Bio-fungicide, Agricultural Technologies, BAURES, Bangladesh Agril. Univ. Mymensingh, Bangladesh. 18 p.

Johnston , P. R. 2000. The importance of phylogeny in understanding of host relationships within Colletotrichum. In: Prusky D, Dickman M.B. Freeman S, eds. Colletotrichum host specificity, pathogenicity and host-pathogen interactions. St. Paul, Minnesota: APS. 21-28 p.

Lo, C. T., Nelson, E. B., and Harman, G. E. 1996. Biological control of turfgrass diseases with a rhizosphere competent strain Trichoderma harzianum. Plant Disease, 80:736-741.

MacHardy, W. E., Gadoury, D. M. and Gessler, C. 2001. Parasitic and biological fitness of Venturia inaequalis: relationship to disease management strategies. Plant Disease, 85:1036-1051.

Mamatha, T., Lokesh, S. and Ravishankar, V. R. 2000. Impact of seed mycoflora of forest tree seeds and their management . Proc. of 2001 National seminar of seed Science and Technology in the millennium. Mysore, India: Department of Studies in Applied Botany and Biotechnology, 106-108 pp.

Mariau, D. 2001. Diseases of Tropical Tree Crops. Oxford \& IBM Publishing Co.

Mondal, S. N. and Timmer, L. W. 2002. Environmental factors affecting pseudothecial development and ascospore production of Mycosphaerella citri, the causal of citrus greasy spot. Phytopathology, 92:1267-1275.

Mostofa, G. M. 2009. Efficacy of BAUBiofungicide and fungicides in controlling diseases of soyabean. M.S. Theis, Dept. of Plant Pathol. BAU, Mymensingh, Bangladesh.

Morton, Julia F. 1987. Fruits of Warm Climates. Creative Resources Systems, Inc. 383-836 pp.

Pathak, V. N. 1980. Diseases of fruit crops. Oxford IBH publishing Co. New Delhi. 12-22 pp.

Pathak, V. N. 1986. Diseases of Fruit Crops. Second printing 1986. Oxford \& IBM Publishing Co., New Delhi, 151-164 pp.
Peterson, R. A. 1986. Mango Diseases. Prcceeding of CSIRO 1st Australian Mango Research Workshop, CSRI, Cairns, 233-247 pp.

Pinkerton, J. N., Johnson, K. B., Stone, J. K. and Ivors, K. L. 1998. Factors affecting the release of ascospores of Anisogramma anomala. Phytopathology, 88:122-128.

Ploetz, R.C., Zentmyer, G.A., Nishijima, W.T., Pohrbach, K.G. and Ohr, H.D. 1998. Compendium of Tropical Fruit Diseases. APS Press. The American Phytopathological Society, 33-34 pp.

Rahman, M. A., T. Ansari, H., Meah, M. B. and Yoshida, T. 2003. Prevalence and pathogenicity of guava anthracnose with special emphasis on varietal reaction. Pakistan Journal of Biological Sciences, 6(3): 234-241.

Rai, V. R. and Mamatha, T. 2005. Seedling diseases of some important forest tree species and their management. In. Working papers of the Finnish Forest Research Institue, $11 \mathrm{p}$.

Rawal, R.D. 1990. Fungal and bacterial diseases of fruit crops. A decade of research on diseases of horticultural crops under AICRIP (1980-1989). Presented at a group discussion of plant pathologists working in coordinated projects of horticulture, held at IIHR during June 14-15, 1990.

Rowe, R. C. and Beute, M. K. 1975. Ascospore formation and discharge by Calonectria crotalariae. Phytopathology, 65:393-398.

Shultana, R., Hossain, I., Ahmed, S. and Mamun, M. A. A. 2009. Efficacy of BAUBiofungicide in controlling leaf spot of wheat (Tritichum aestivum). Eco-friendly Agricultural Journal, 2(2):392-395.

Singh, R. S. 1998. Plant Disease. 7th edition. Oxford and IBH Publishing Co. New Delhi, 97-98 pp.

Sutton, T. B. 1981. Production and dispersal of ascospores and conidia by Physalospora obtuse and Botryosphaeria dothidea in apple orchards. Phytopathology, 71:584-589. 
